\title{
EFFECT OF PLATELET RICH FIBRIN AND MESENCHYMAL STEM CELL ON MYOBLAST AND FIBROBLASTS RATIO IN RABBIT MUSCLE DEFECT
}

\author{
Dwikora Novembri Utomo $^{1^{*}}$, Mohammad Zaim Chilmi ${ }^{1}$, Angga Fiandana ${ }^{2}$ \\ ${ }^{1}$ Staff of Orthopaedic and Traumatology Department, Faculty of Medicine, Universitas \\ Airlangga/Dr Soetomo General Hospital, Surabaya \\ ${ }^{2}$ Resident of Orthopaedic and Traumatology Department, Faculty of Medicine, Universitas \\ Airlangga/Dr Soetomo General Hospital, Surabaya \\ *Corresponding Author: Dwikora Novembri Utomo, Senior Consultant of Orthopedic and \\ Traumatology Department, Faculty of Medicine, Universitas Airlangga, Jl. Mayjen Prof. Dr. \\ Moestopo 6-8, Surabaya \\ E-mail: dwikora_utomo@yahoo.com
}

\begin{abstract}
ABSTRAK
Latar Belakang: Salah satu problematika di bidang Orthopaedi yang seringkali memberikan hasil outcome yang kurang memuaskan adalah penanganan mengenai cedera otot. Hal ini disebabkan proses penyembuhannya berlangsung sangat lambat dan memberikan outcome yang belum optimal karena menghasilkan jaringan parut.
\end{abstract}

Tujuan: Mengetahui efek pemberian platelet-rich fibrin dan allogenic mesenchymal stem cell pada regenerasi otot yang cedera melalui rasio jumlah sel myoblast terhadap jumlah sel fibroblast yang terbentuk.

Metode: Penelitian ini merupakan true experimental dengan rancangan randomized pre and post test with control group design. Kelompok perlakuan meliputi pemberian allogenic mesenchymal stem cell (MSC), platelet rich fibrin (PRF), dan kombinasi keduanya. Subjek penelitian adalah New Zealand White Rabbit yang dilakukan insisi pada otot gastrocnemius. Evaluasi kualitas otot dilakukan pada minggu kedua dan keempat melalui pemeriksaan histologi berupa rasio sel myoblast terhadap fibroblast.

Hasil: Pada evaluasi minggu kedua, pemberian allogenic MSC dikombinasi dengan PRF memberikan hasil signifikan terhadap peningkatan rasio sel myoblast terhadap fibroblast. Sedangkan evaluasi minggu keempat, pemberian ketiga kelompok perlakuan memberikan hasil signifikan terhadap rasio sel myoblast terhadap fibrobast.

Kesimpulan: Pemberian allogenic MSC yang dikombinasi dengan PRF dapat meningkatkan kualitas penyembuhan cedera otot kelinci New Zealand White Rabbit secara pemeriksaan histologi.

Kata kunci: allogenic MSC, PRF, myoblast, fibroblast

\begin{abstract}
Background: One of the problems in Orthopedics which often results in less satisfactory outcomes is the muscle injuries treatment. This is due to slow healing process and outcome has not been optimal because it produces scar tissue.

Purpose: To evaluate effect of platelet rich fibrin and allogenic mesenchymal stem cell on muscle regeneration through comparation of myoblast and fibroblast ratio.

Methods: This research is true experimental with randomized pre and post test with control group design. The treatment group included administering allogenic mesenchymal stem cells (MSC), rich fibrin platelets (PRF), and a combination of both. The study subjects were New Zealand White Rabbit which gastrocnemius muscle is incised. Muscle quality evaluation was done in the second and fourth weeks through histology examination in the form of myoblast cell ratio to fibroblast.
\end{abstract}


Artikel Penelitian

Vol 7 No. 2, Oktober 2018

ISSN 2460-8742

http://journal.unair.ac.id/ORTHO@journal-orthopaedi-and-traumatology-surabaya-media-104.html

Results: In the second week evaluation, administering allogenic MSC combined with PRF gave significant results to an increase in myoblast cell ratio to fibroblast. While evaluation of fourth week, giving of three treatment groups gave significant result to myoblast cell ratio to fibroblast. Conclusion: Allogenic MSC administration combined with PRF can improve New Zealand White Rabbit muscle healing quality by histological examination.

Keywords: allogenic MSC, PRF, myoblast, fibroblast

\section{PENDAHULUAN}

Salah satu problematika di bidang Orthopaedi dan Traumatologi yang seringkali memberikan hasil outcome yang kurang memuaskan adalah penanganan mengenai cedera otot. ${ }^{1,2}$ Hal ini disebabkan proses penyembuhan dari cedera otot berlangsung sangat lambat dan seringkali dengan outcome fungsional yang belum optimal. Cedera pada otot merupakan salah satu jenis cedera tersering pada atlet. Sebagai contoh, pada bidang olahraga sepakbola, menurut Ekstrand et al. dalam American Journal of Sport Medicine, tahun 2011 di Amerika Serikat, diperkirakan sebanyak 20-37\% dari atlet sepak bola Amerika Serikat pernah menderita cedera otot sepanjang perjalanan karir. Problematika yang ada tidak hanya kualitas dari jaringan otot yang terbentuk dari jaringan fibrous saja yang tidak baik, namun serabut otot baru yang terbentuk juga tidak cukup cepat karena proses penyembuhan yang lama dengan rentang waktu penyembuhan antara 3 minggu hingga 6 bulan tergantung dari derajat cedera. ${ }^{3}$

Tatalaksana penderita dengan cedera otot secara umum masih kontroversial.
Beberapa ilmuwan memilih terapi konservatif dengan RICE (Rest, Ice, Compression, Elevation) saat fase akut dan muscle exercise setelah fase akut mereda. Sebagian mengaplikasikan pemberian gelombang ultrasound untuk menstimulasi muscle healing, namun sebagian yang lain memilih terapi operatif dengan pembedahan, sampai dengan terapi terbaru yaitu pemberian growth factor maupun stem cell. ${ }^{4}$ Stem cell diketahui memiliki sifat totipotent, pluripotent, dan unipotent serta multipotent. Sehingga satu sel induk dapat mengalami proliferasi maupun diferensiasi menjadi sel yang diinginkan., ${ }^{5,6}$ Platelet merupakan salah satu penyusun dari sel darah yang memiliki sifat potent regenerative cell. ${ }^{7}$ Hal ini dikarenakan sifatnya yang kaya akan growth factor. Telah diketahui bahwa growth factor dapat memicu produksi kolagen, mitosis sel, angiogenesis, osteogenesis, diferensiasi sel, dan merangsang stem cell bergerak menuju injury site agar mempercepat terjadinya regenerasi sel. ${ }^{8,9}$

Platelet ini diproses melalui mesin sentrifuse sehingga menjadi platelet rich plasma (PRP) yang saat ini banyak 
Artikel Penelitian

Vol 7 No. 2, Oktober 2018

ISSN 2460-8742

http://journal.unair.ac.id/ORTHO@journal-orthopaedi-and-traumatology-surabaya-media-104.html

digunakan sebagai sumber alami growth factor dalam regenerasi sel dan soft tissue healing. Platelet Rich Fibrin (PRF) merupakan generasi kedua dari PRP, pertama kali diperkenalkan di Prancis oleh Choukroun et al. pada tahun 2001, untuk operasi Bedah Mulut dan Maksilofasial karena kandungan growth factor yang tinggi. ${ }^{10,11}$ Kelebihan PRF dibandingkan PRP adalah cara pembuatannya yang lebih mudah dan tidak memerlukan penambahan senyawa kimiawi baru dari proses pembuatannya. $^{12}$

\section{METODOLOGI PENELITIAN}

Penelitian ini merupakan true experimental dengan rancangan randomized post test only with control group design. Pada penelitian ini terdapat 4 kelompok yaitu kelompok kontrol 1 (kelompok A), perlakuan 1 diberikan platelet rich fibrin (kelompok B), perlakuan 2 diberikan allogenic mesenchymal stem cell (kelompok C) dan perlakuan 3 diberikan (kelompok D) platelet rich fibrin dan allogenic mesenchymal stem cell. Sebelum membagi menjadi 4 kelompok, tiap kelompok akan dilakukan randomisasi.

Subyek penelitian adalah otot gastrocnemius kelinci dewasa dengan ras New Zealand White Rabbit dengan model cedera otot dengan kriteria inklusi sebagai berikut:
1. Jenis kelamin jantan

2. Umur dewasa 5-7 bulan

3. Berat rata-rata $2500 \mathrm{~g} \pm 500 \mathrm{~g}$

4. Tidak cacat tubuh

5. Sehat dan gerak aktif

Kriteria eksklusi sebagai berikut :

1. Terjadi apabila umur kurang dari 6 bulan dan lebih dari 9 bulan

2. Kelinci menderita sakit atau infeksi lain saat pelaksaan penelitian

Sampel penelitian ini adalah kelinci New Zealand White Rabbit dengan besar sampel ditentukan berdasarkan jumlah ulangan.

Berdasarkan perhitungan rumus, jumlah total unit eksperimen untuk penelitian ini adalah 6,15 dengan pembulatan 7 sampel. Kemungkinan kegagalan didapatkan dengan memperhitungkan faktor resiko (f) sebesar $10 \%$, sehingga berdasarkan rumus di atas minimal digunakan sampel sebanyak 8 sampel. Jika digunakan empat kelompok maka jumlah total sampel yang diperlukan adalah 32 sampel.

Pengelompokkan dilakukan secara acak sederhana dengan cara lotere. Masingmasing kelinci diberi nomor dan kemudian dilakukan pengundian ke setiap kelompok dengan jumlah total empat kelompok. 
Artikel Penelitian

Vol 7 No. 2, Oktober 2018

http://journal.unair.ac.id/ORTHO@journal-orthopaedi-and-traumatology-surabaya-media-104.html

Unit analisis adalah model cedera otot gastrocnemius kelinci yang diberikan allogenic mesenchymal stem cells dan platelet-rich fibrin.

\section{HASIL DAN PEMBAHASAN}

Penelitian ini membandingkan efektivitas pemberian allogenic mesencymal stem cell dan platelet rich fbrin pada regenerasi otot yang cedera. Hasil penelitian ditampilkan dalam jumlah sel myoblast yang terbentuk dan jumlah sel fibroblast yang terbentuk seperti tampak pada Gambar 1.
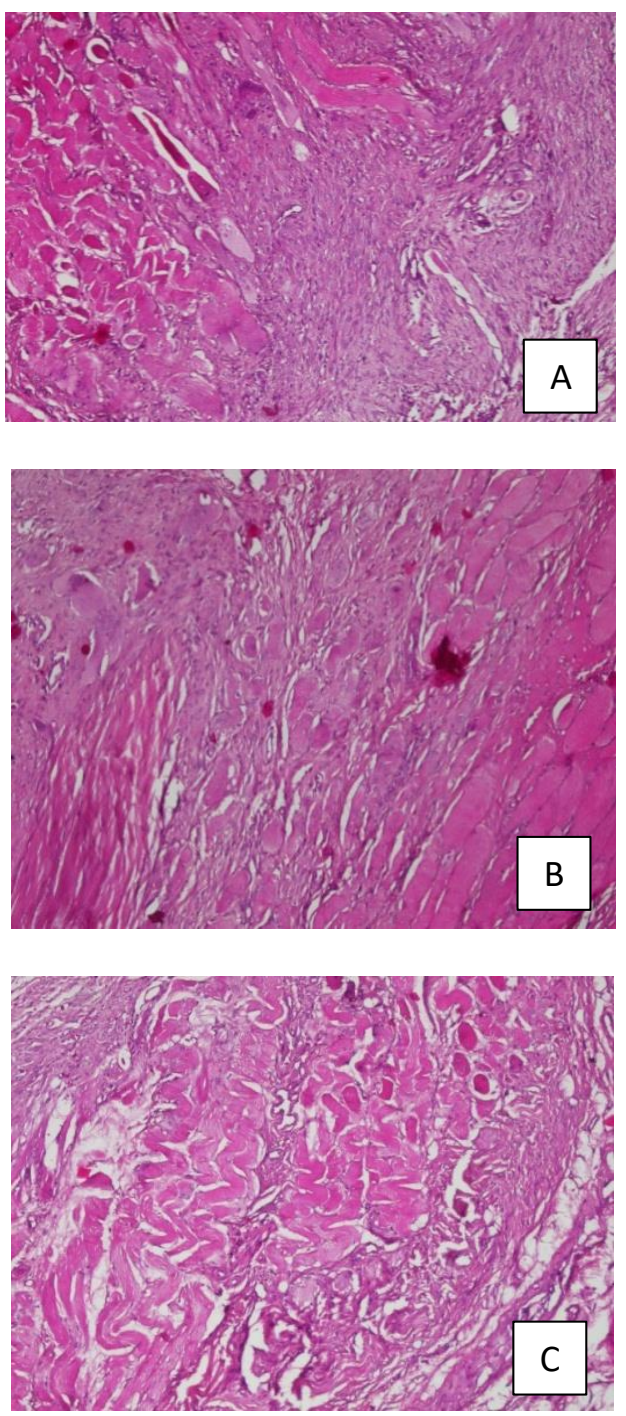

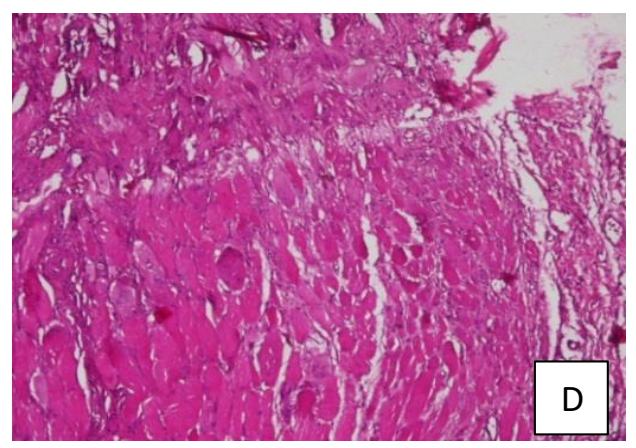

Gambar 1. Hasil kultur yang diwarnai dengan Hematoksilin Eosin (HE) perbesaran 10 kali pada (A) kelompok kontrol (B) kelompok pemberian platelet-rich fibrin (C) kelompok pemberian allogenicmesenchymal stem cel l(D) kelompok pemberian plateletrich fibrin dan allogenic mesenchymal stem cell

Hitung jumlah sel myoblast dan jumlah sel fibroblast dilakukan di bawah pengamatan mikroskop dengan pewarnaan Hematoksilin Eosin (HE) dengan satuan jumlah/lapang pandang. Penghitungan dilakukan dengan melihat di 5 lapang pandang pada setiap kelompok perlakuan, lalu hasil penghitungan dari 5 lapang pandang tersebut dihitung rata-ratanya. Penghitungan jumlah sel myoblast dan sel fibroblast dilakukan setelah minggu kedua dan keempat setelah intervensi.

Hasil pengukuran pada kelompok minggu kedua berupa jumlah sel myoblast, jumlah sel fibroblast dan rasio jumlah sel myoblast dibanding jumlah sel fibroblast tersaji dalam Tabel 1 berikut. 
Tabel 1. Hasil penghitungan jumlah sel myoblast, sel fibroblast, dan rasio sel myoblast terhadap sel fibroblast pada kelompok minggu kedua

\begin{tabular}{|c|c|c|c|c|}
\hline Kelompok Perlakuan & $\begin{array}{c}\text { Sampel } \\
\text { penelitian }\end{array}$ & $\begin{array}{l}\text { Jumlah Sel } \\
\text { Myoblast }\end{array}$ & $\begin{array}{l}\text { Jumlah Sel } \\
\text { Fibroblast }\end{array}$ & $\begin{array}{c}\text { Rasio Sel Myoblast } \text { : } \\
\text { Sel Fibroblast }\end{array}$ \\
\hline \multirow[t]{5}{*}{ Kelompok A } & 1 & 98 & 72 & 1,36 \\
\hline & 2 & 94 & 79 & 1,18 \\
\hline & 3 & 88 & 97 & 0,90 \\
\hline & 4 & 81 & 63 & 1,28 \\
\hline & 5 & 97 & 74 & 1,31 \\
\hline \multirow[t]{2}{*}{ Rata-rata } & & 91,6 & 77 & 1,21 \\
\hline & 1 & 95 & 75 & 1,26 \\
\hline \multirow[t]{4}{*}{ Kelompok B } & 2 & 75 & 68 & 1,10 \\
\hline & 3 & 76 & 54 & 1,40 \\
\hline & 4 & 110 & 81 & 1,35 \\
\hline & 5 & 107 & 84 & 1,27 \\
\hline \multirow[t]{2}{*}{ Rata-rata } & & 92,6 & 72,4 & 1,28 \\
\hline & 1 & 103 & 75 & 1,37 \\
\hline \multirow[t]{4}{*}{ Kelompok C } & 2 & 94 & 69 & 1,36 \\
\hline & 3 & 105 & 78 & 1,34 \\
\hline & 4 & 98 & 80 & 1,22 \\
\hline & 5 & 93 & 90 & 1,03 \\
\hline \multirow[t]{2}{*}{ Rata-rata } & & 98,6 & 78,4 & 1,26 \\
\hline & 1 & 142 & 98 & 1,44 \\
\hline \multirow[t]{4}{*}{ Kelompok D } & 2 & 138 & 93 & 1,48 \\
\hline & 3 & 133 & 96 & 1,38 \\
\hline & 4 & 120 & 76 & 1,57 \\
\hline & 5 & 124 & 83 & 1,49 \\
\hline Rata-rata & & 131,4 & 89,2 & 1,47 \\
\hline
\end{tabular}

$\mathrm{H}$

Hasil penelitian menunjukkan bahwa pada kelompok minggu kedua, hitung jumlah sel myoblast lebih banyak dibandingkan sel fibroblast dengan rasio

sel myoblast terhadap sel fibroblast paling tinggi pada kelompok kombinasi platelet rich fibrin dan allogenic mesenchymal stem cell. 

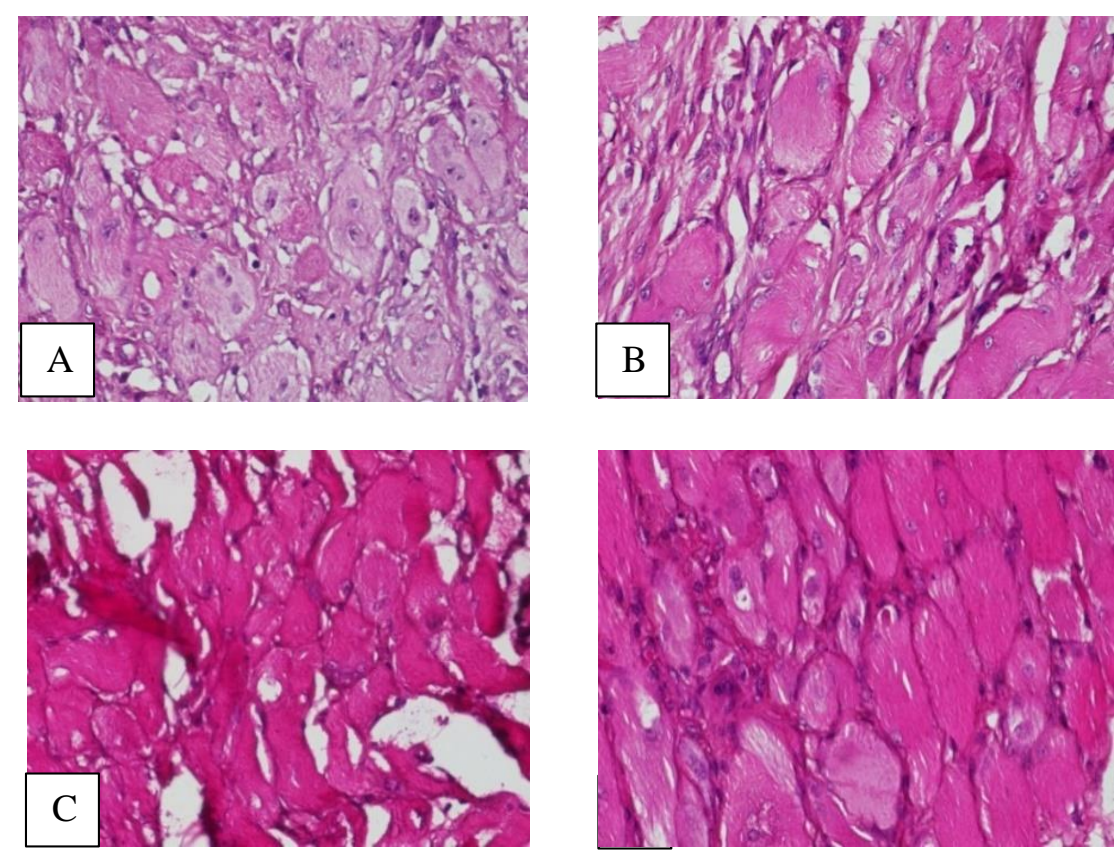

Gambar 2. Hasil kultur yang diwarnai dengan Hematoksilin Eosin (HE) perbesaran 40 kali pada (A) kelompok kontrol (B) kelompok plateletrich fibrin (C) kelompok allogenic mesenchymal stem cell (D) kelompok kombinasi platelet rich fibrin dan allogenic mesenchymal stem cell pada kelompok minggu kedua

Hasil pengukuran pada kelompok minggu keempat berupa jumlah sel myoblast, jumlah sel fibroblast dan rasio jumlah sel myoblast dibanding jumlah sel fibroblast dapat dilihat pada Tabel 2. 
Artikel Penelitian

Vol 7 No. 2, Oktober 2018

ISSN 2460-8742

http://journal.unair.ac.id/ORTHO@journal-orthopaedi-and-traumatology-surabaya-media-104.html

Tabel 2. Hasil penghitungan jumlah sel myoblast, sel fibroblast, dan rasio sel myoblast terhadap sel fibroblast pada kelompok minggu keempat

\begin{tabular}{|c|c|c|c|c|}
\hline $\begin{array}{c}\text { Kelompok } \\
\text { Perlakuan }\end{array}$ & $\begin{array}{c}\text { Sampel } \\
\text { penelitian }\end{array}$ & $\begin{array}{c}\text { Jumlah Sel } \\
\text { Myoblast }\end{array}$ & $\begin{array}{l}\text { Jumlah Sel } \\
\text { Fibroblast }\end{array}$ & $\begin{array}{c}\text { Rasio Sel } \\
\text { Myoblast/Sel } \\
\text { Fibroblast }\end{array}$ \\
\hline \multirow{5}{*}{ Kelompok A } & 1 & 143 & 98 & 1,45 \\
\hline & 2 & 134 & 105 & 1,27 \\
\hline & 3 & 169 & 101 & 1,67 \\
\hline & 4 & 152 & 119 & 1,27 \\
\hline & 5 & 167 & 120 & 1,39 \\
\hline Rata-rata & & 153 & 108,6 & 1,41 \\
\hline \multirow[t]{5}{*}{ Kelompok Otot B } & 1 & 179 & 98 & 1,82 \\
\hline & 2 & 177 & 103 & 1,71 \\
\hline & 3 & 181 & 108 & 1,67 \\
\hline & 4 & 188 & 110 & 1,70 \\
\hline & 5 & 164 & 107 & 1,53 \\
\hline Rata-rata & & 177,8 & 105,2 & 1,69 \\
\hline \multirow[t]{5}{*}{ Kelompok Otot C } & 1 & 144 & 84 & 1,71 \\
\hline & 2 & 164 & 94 & 1,74 \\
\hline & 3 & 143 & 81 & 1,76 \\
\hline & 4 & 149 & 88 & 1,69 \\
\hline & 5 & 169 & 98 & 1,72 \\
\hline Rata-rata & & 153,8 & 89 & 1,72 \\
\hline \multirow[t]{5}{*}{ Kelompok Otot D } & 1 & 159 & 88 & 1,80 \\
\hline & 2 & 139 & 78 & 1,78 \\
\hline & 3 & 157 & 91 & 1,72 \\
\hline & 4 & 171 & 89 & 1,92 \\
\hline & 5 & 154 & 96 & 1,60 \\
\hline Rata-rata & & 156 & 88,4 & 1,76 \\
\hline
\end{tabular}

Hasil penelitian menunjukkan

bahwa hasil pada kelompok empat minggu, hitung jumlah sel myoblast lebih banyak dibandingkan jumlah sel fibroblast. Rasio sel myoblast terhadap sel fibroblast paling tinggi pada kelompok otot platelet-rich fibrin dan allogenic mesenchymal stem cell pada kelompok minggu kedua dan keempat (Gambar 3).

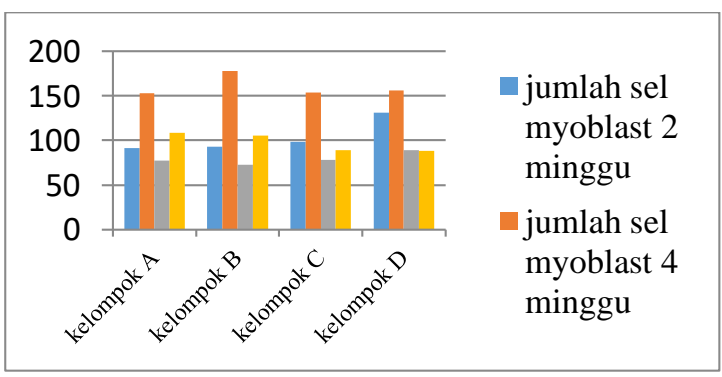

Gambar 3. Perbandingan rata-rata jumlah sel Myoblast dan rata-rata jumlah sel Fibroblast pada kelompok minggu kedua dan keempat

Uji tes anova didapatkan bahwa pada rasio sel myoblast terhadap sel fibroblast kelompok dua minggu didapatkan perbedaan yang bermakna antara kelompok perlakuan $(\mathrm{p}=0,034)$. Analisis post hoc menggunakan Tukey test didapatkan perbedaan yang bermakna terlihat antara rasio sel myoblast terhadap sel fibroblast kelompok kontrol sebesar $1,20 \pm 0,18$ dengan kelompok otot platelet 
Artikel Penelitian

Vol 7 No. 2, Oktober 2018

ISSN 2460-8742

http://journal.unair.ac.id/ORTHO@journal-orthopaedi-and-traumatology-surabaya-media-104.html

rich fibrin minggu kedua sebesar $1,28 \pm 0,11(\mathrm{p}=0,842)$.

Rasio sel myoblast terhadap sel fibroblast kelompok kontrol minggu kedua dibandingkan kelompok allogenic mesenchymal stem cell $(1,20 \pm 0,18$ vs $1,26 \pm 0,14 ; \mathrm{p}=0,902)$; rasio sel myoblast terhadap sel fibroblast kelompok otot kontrol minggu kedua dibandingkan dengan kelompok otot platelet-rich fibrin dan allogenic mesenchymal stem cell minggu kedua $(1,20 \pm 0,18$ vs $1,47 \pm 0,06$; $\mathrm{p}=0,030$ ); rerata rasio sel myoblast terhadap sel fibroblast kelompok plateletrich fibrin minggu kedua dibandingkan dengan kelompok allogenic mesenchymal stem cell minggu kedua $(1,28 \pm 0,11$ vs $1,26 \pm 0,14 ; \quad p=0,999) ;$ rerata rasio sel myoblast terhadap sel fibroblast kelompok platelet-rich fibrin minggu kedua dengan kelompok otot platelet-rich fibrin dan mesenchymal stem cell 2 minggu $(1,28 \pm 0,11$ vs $1,47 \pm 0,06 ; p=0,138)$; rerata rasio sel myoblast terhadap sel fibroblast kelompok otot allogenic mesenchymal stem cell 2 minggu dengan dengan kelompok otot platelet-rich fibrin dan mesenchymal stem cell 2 minggu $(1,26 \pm 0,14$ vs $1,47 \pm 0,06 ; p=0,108)$. Grafik rasio sel myoblast terhadap sel fibroblast dapat dilihat pada Gambar 4 berikut.

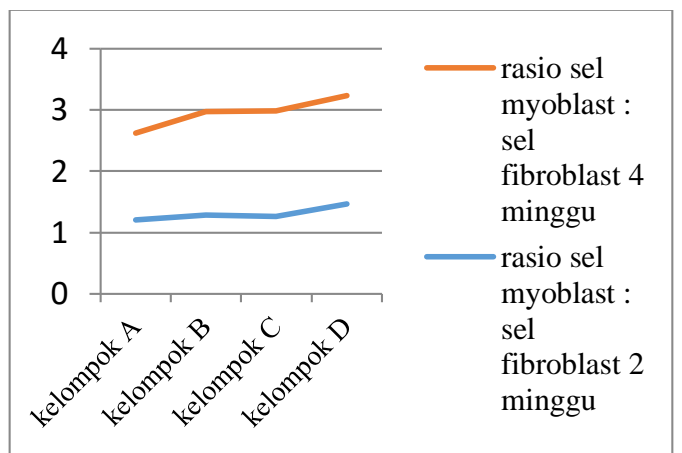

Gambar 4. Grafik perbandingan rasio sel myoblast terhadap sel fibroblast

Hasil ini menunjukkan bahwa terdapat perbedaan variasi yang bermakna secara statistik pada rata-rata rasio sel myoblast terhadap sel fibroblast pada kelompok dua minggu dan kemampuan untuk regenerasi otot dengan melihat dari rasio tersebut paling tinggi pada kelompok kombinasi pemberian allogenic mesenchymal stem cell dan platelet-rich fibrin.

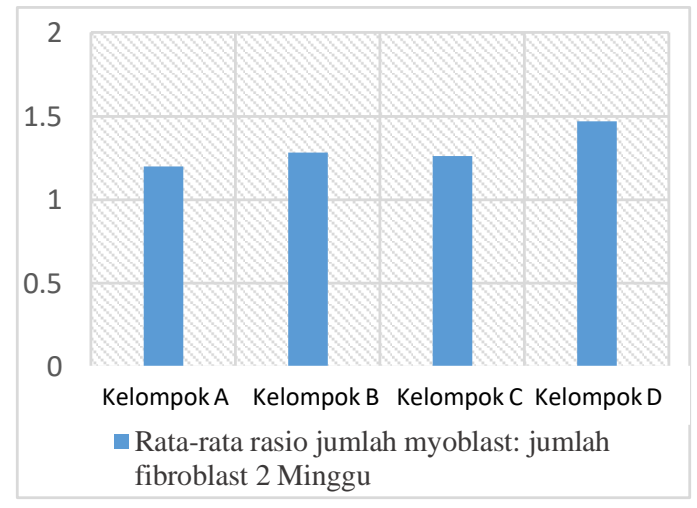

Gambar 5. Grafik perbandingan rata-rata rasio sel myoblast dan sel fibroblast pada kelompok minggu kedua

Uji tes anova didapatkan bahwa pada rasio sel myoblast terhadap sel fibroblast kelompok 4 minggu didapatkan perbedaan yang bermakna antara kelompok perlakuan $(\mathrm{p}=0,001)$. Analisis 
Artikel Penelitian

Vol 7 No. 2, Oktober 2018

ISSN 2460-8742

http://journal.unair.ac.id/ORTHO@journal-orthopaedi-and-traumatology-surabaya-media-104.html

post hoc menggunakan Tukey didapatkan perbedaan yang bermakna terlihat antara rasio sel myoblast terhadap sel fibroblast kelompok otot kontrol 4 minggu dengan kelompok otot platelet-rich fibrin 4 minggu $(1,41 \pm 0,16 \quad$ vs $1,68 \pm 0,10$; $\mathrm{p}=0,008)$; rasio sel myoblast terhadap sel fibroblast kelompok otot kontrol 4 minggu dengan kelompok otot allogenic mesenchymal stem cell 4 minggu $(1,41 \pm 0,16$ vs $1,72 \pm 0,02 ; p=0,003)$; rasio sel myoblast terhadap sel fibroblast kelompok otot kontrol 4 minggu dengan kelompok otot fibrin dan allogenic mesenchymal stem cell 4 minggu $(1,41 \pm 0,16$ vs $1,76 \pm 0,11 ; p=0,001)$; antara rerata rasio sel myoblast terhadap sel fibroblast kelompok otot platelet-rich fibrin 4 minggu dengan kelompok otot allogenic mesenchymal stem cell 4 minggu $(1,68 \pm 0,10$ vs $1,72 \pm 0,02 ; \mathrm{p}=0,952)$; antara rerata rasio sel myoblast terhadap sel fibroblast kelompok otot platelet-rich fibrin 4 minggu dengan kelompok otot platelet-rich fibrin dan mesenchymal stem cell 2 minggu $(1,68 \pm 0,10$ vs $1,76 \pm 0,11$ $(\mathrm{p}=0,708)$; antara rerata rasio sel myoblast terhadap sel fibroblast kelompok otot allogenic mesenchymal stem cell 4 minggu dengan kelompok otot platelet-rich fibrin dan mesenchymal stem cell 4 minggu $(1,72 \pm 0,02$ vs $1,76 \pm 0,11(\mathrm{p}=0,945)$. Hasil ini menunjukkan bahwa terdapat perbedaan yang bermakna secara statistik pada rata-rata rasio sel myoblast terhadap sel fibroblast pada kelompok empat minggu dan kemampuan untuk regenerasi otot dengan melihat dari rasio tersebut paling tinggi pada kelompok kombinasi pemberian platelet-rich fibrin dan allogenic mesenchymal stem cell yang bermakna secara statistik.

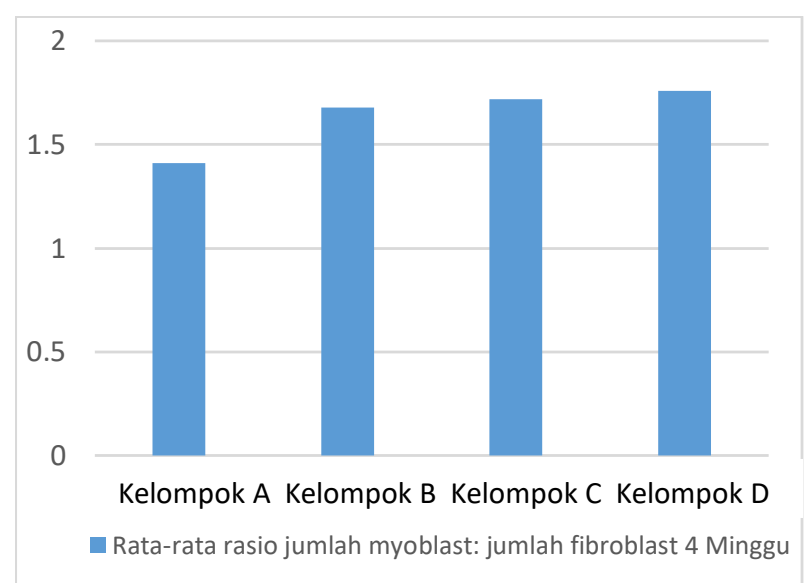

Gambar 6. Grafik perbandingan rata-rata rasio sel Myoblast dan sel Fibroblast pada kelompok minggu keempat

Pada uji anova kelompok minggu keempat didapatkan bahwa rasio sel myoblast terhadap sel fibroblast mengalami perbedaan yang bermakna antara kelompok perlakuan dibandingkan kelompok kontrol $(\mathrm{p}=0,001)$. Analisis post hoc menggunakan Tukey test didapatkan perbedaan yang bermakna terlihat antara rasio sel myoblast terhadap sel fibroblast kelompok kontrol dibandingkan dengan kelompok pemberian PRF, allogenic mesenchymal stem cell, dan PRF 
Artikel Penelitian

Vol 7 No. 2, Oktober 2018

ISSN 2460-8742

http://journal.unair.ac.id/ORTHO@journal-orthopaedi-and-traumatology-surabaya-media-104.html

dikombinasi dengan allogenic MSC dengan nilai $\mathrm{p}$ berturut-turut adalah 0,008; 0,003; dan 0,001 (semula nilai $\mathrm{p}<0,05$ ). Hal ini berbeda dengan hasil evaluasi pada minggu kedua, dikarenakan waktu evaluasi 2 minggu belum cukup bagi sel myoblast yang baru untuk tumbuh dan berkembang secara optimal

Apabila peneliti membandingkan rasio sel myoblast terhadap sel fibroblast pada pemberian PRF terhadap pemberian allogenic MSC baik pada evaluasi 2 maupun 4 minggu maka tidak didapatkan perbedaan yang signifikan. Hal ini disebabkan pemberian kedua faktor diatas sama-sama menyebabkan peningkatan jumlah sel myoblast dan mengurangi jumlah sel fibroblast yang terbentuk secara seimbang. Berturut-turut nilai p nya adalah 0,999 dan 0,952 (semua nilai $\mathrm{p}>0,05$ ). Hasil di atas sesuai dengan penelitian Metineren et al pada 20 ekor tikus yang diberikan PRF pada robekan tendon achiles. ${ }^{13}$

Hal yang sama juga didapatkan oleh penelitian yang dilakukan oleh Matthias et al pada 15 ekor kelinci yang diberikan pemberian stem cell berupa sediaan gel terhadap defek pada otot tibialis anterior, didapatkan pemberian stem cell setelah 4 minggu dapat mengurangi terjadinya jaringan fibrous. ${ }^{14}$

\section{KESIMPULAN DAN SARAN}

\section{Kesimpulan}

1. Terdapat peningkatan rasio sel myoblast terhadap sel fibroblast pada penyembuhan cedera otot gastrocnemius New Zealand White Rabbit pada kelompok pemberian PRF yang dikombinasi dengan allogenic MSC setelah evaluasi selama 2 minggu.

2. Terdapat peningkatan rasio sel myoblast terhadap sel fibroblast pada penyembuhan cedera otot gastrocnemius New Zealand White Rabbit pada kelompok pemberian PRF, allogenic MSC, dan pemberian kombinasi keduanya setelah evaluasi selama 4 minggu.

3. Pemberian kombinasi PRF dan allogenic MSC memberikan rasio sel myoblast terhadap fibroblast tertinggi dibanding kelompok percobaan lainnya.

\section{Saran}

1. Perlu dilakukan penelitian untuk mengevaluasi secara immunohistokimia terhadap regenerasi sel otot dan pencegahan jaringan parut yang terjadi.

2. Perlu dilakukan penelitian lanjutan terhadap evaluasi penyembuhan sel otot yang terjadi melalui pemeriksaan biomekanik terhadap kekuatan otot 
Artikel Penelitian

Vol 7 No. 2, Oktober 2018

http://journal.unair.ac.id/ORTHO@journal-orthopaedi-and-traumatology-surabaya-media-104.html

yang terbentuk terhadap pemberian

PRF dan allogenic MSC.

\section{REFERENSI}

1. Borie, E., Olivi, D., Orsi, I., et al. Platelet-rich fibrin application in dentistry: a literature review. J Clin Exp Med 2015.

2. Borrione P, Grasso L, Chierto E, et al.2014. Experimental model for the study of the effects of platelet-rich plasma on the early phases of muscle healing. Blood Transfus;12(Suppl 1):s221-8.

3. Desai, C., Mahindra, U., Kini, Y., Bakshi, M. Use of platelet-rich fibrin over skin wounds: Modified secondary intention healing. Journal of Cutaneus and Aesthetic Surgery. 2013.

4. Dimauro I, Grasso L, Fittipaldi S, et al. 2014. Platelet-rich plasma and skeletal muscle healing: a molecular analysis of the early phases of the regeneration process in an experimental animal model. PLoS One;9(7):e102993.

5. Ekstrand, J, Hagglund, M., Walden, M. Epidemiology of Muscle Injuries in Professional Football (Soccer). American Journal of Sports Medicine. 2011.

6. Gassling V, Douglas T, Warnke PH, Açil Y, Wiltfang $\mathbf{J}$ and Becker ST. Platelet-rich fibrin membranes as scaffolds for periosteal tissue engineering. Clin Oral Implants Res 2010; 21: 543-549.

7. Gigante et al. 2012. Platelet rich fibrin matrix effect on skeletal muscle lessions: An experimental study. Journal of biological regulator and homeostatic agents Vol 26, no.3, 475-484.

8. Hinds, S., et al. Improved Tissue Culture Condition for Engineered Skeletal Muscle Sheet. Department of Basic Sciences, New York University, 345 East 24th Street, New York, NY 10010,USA. January 2013.

9. Järvinen, Tero Ah, Markku Järvinen, and Hannu Kalimo. 2013. Regeneration of Injured Skeletal Muscle after the Injury. Muscles, ligaments and tendons journal 3(4): 337-45.

10. Jones, A.E., Price, F.D., F. Le Grand et al. 2015. Wnt $/ \beta$-catenin controls follistatin signalling to regulate satellite cell myogenic potential, Skeletal Muscle, vol. 5, article 14.

11. Khiste, S., Tari, R., Platelet-Rich Fibrin as a Biofuel for Tissue Regeneration. Hindawi Publishing Corporation, ISRN Biomaterials. 2013

12. Kogdere, N., Baykul, T., Findik, Y. The use of platelet-rich fibrin (PRF) and PRF-mixed particulated autogenous bone graft in the treatment of bone defects: An experimental and histomorphometrical study. Dental Research Journal. 2015

13. Metineren, H., Dulgeroglu, T., Metineren, M., Aydin, E., Kocak, C. Effectiveness of platelet-rich fibrin on tendon healing: experimental study in a rat model. Int J Clin Exp Med. 2016

14. Matthias, et al. 2018. Volumetric muscle loss injury repair using in situ fibringel cast seeded with musclederived stem cells (MDSCs). Stem cell research 27 (2018) 65-73. 